Pamiętnik Literacki 2019, 2, s. 101-114
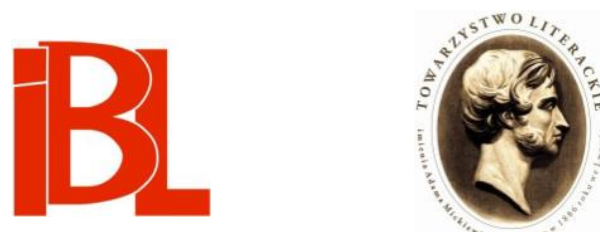

\title{
Pod ciężarem oświecenia. Stanisława Brzozowskiego XVIII-wieczne biografie i diagnozy w powieści "Sam wśród ludzi”
}

Piotr Misztela 
Pamiętnik Literacki CX, 2019, z. 2, PL ISSN 0031-0514

DOI: $10.18318 / \mathrm{pl} .2019 .2 .6$

PIOTR MISZTELA Instytut Badań Literackich PAN, Warszawa

\section{POD CIEZŻAREM OŚWIECENIA STANISŁAWA BRZOZOWSKIEGO XVIII-WIECZNE BIOGRAFIE I DIAGNOZY W POWIEŚCI „SAM WŚRÓD LUDZI”}

\section{Historiozofia a XVIII wiek w perspektywie Stanisława Brzozowskiego}

Namysł nad historią zajmuje poczesne miejsce w biografii intelektualnej Stanisława Brzozowskiego. Wybitna badaczka jego dzieł, Marta Wyka, wskazuje, że autor Wirów uważał przeszłość za „klucz do swojej nowoczesności” (C 369) ${ }^{1}$. Podejście takie, wśród modernistów powszechne, zyskuje rys szczególny u tego akurat twórcy, traktował on bowiem znajomość, a przede wszystkim - zrozumienie dziejów, nie tyle jako pomocne, ile jako warunkujące wszelką aktywność i pożyteczną działalność dla dobra ludzkości². Jak twierdzi Stefan Kołaczkowski, przeświadczeniem Brzozowskiego było, że:

„każdy okruch naszej rzeczywistości wypracowany jest przez historię”, [...] nie masz żadnej rzeczywistości prócz historycznej: „Wszystko, co stanowi treść, zawartość świadomości, może być tylko doświadczeniem, przeżyciem, zdobytym w ciagu historycznego życia ludzkości”’”.

Kołaczkowski proponuje miano historyzmu dla poglądów pisarza, odnotowując jego fascynację filozofią Giambattisty Vica, Georga Wilhelma Friedricha Hegla i Benedetta Crocego. Powołuje się przy tym na kluczowe dla Brzozowskiego elementy systemów myślowych owych trzech uczonych. W przypadku Crocego będzie to uznanie dziejów za jedyną istniejącą rzeczywistość (tym samym zanegowanie dualizmu wskazującego na istnienie wyższego, ponadhistorycznego świata idei),

1 Skrótem tym odsyłam do pracy M. Wy k i Czytanie Brzozowskiego (Kraków 2012). Cytując dzieła S. Brzozowskiego, posługuję się skrótami: L = Legenda Młodej Polski. Studia o strukturze duszy kulturalnej. Kraków-Wrocław 1983. Reprint wyd. 2 (Lwów 1910); - P = Pamiętnik. Wstęp M. Wy ka. Oprac. tekstu, koment. M. U rba n ow s ki. Wrocław 2007; - S = Sam wśród ludzi. Oprac. M. Wy ka. Wrocław 1979. BN I 228. Ponadto stosuję skrót O = J. S n o p e k, Objawienie i oświecenie. Z dziejów libertynizmu w Polsce. Wrocław 1986. Liczby po skrótach oznaczają numery stronic.

2 Charakterystyczne, że Brzozowski nie wymagał tego wyłącznie od tzw. inteligencji; pisał bowiem: „tylko w społeczeństwie, w którym typem dominującym jest świadomy robotnik mięśniowy - pracownikom intelektualnym uda się uzyskać odpowiednią samokontrolę [...]” (L 102).

3 S. Kołaczkowski, Stanisław Brzozowski. W: Portrety i zarysy literackie. Oprac. S. Pigoń. Warszawa 1968, s. 217. Cytaty pochodzą z pracy S. B rzozow s ki e go Idee. Wstęp do filozofii dojrzałości dziejowej (Lwów 1910). 
u Vica - potrzeba „rozwijania inteligencji i woli, tak aby inteligencja [...] umożliwiała woli wybór rzeczy najlepszych pośród rzeczy ludzkich"4. Od Hegla zaczerpnie zaś pisarz „wieczny rewolucjonizm” oraz „zmysł konkretności, cechujaccy jego wiedzę historyczna" 5 . Jako pokłosie myśli niemieckiego filozofa (choć w tym przypadku w obliczu braku wiary Brzozowskiego w „ducha dziejów” - chyba silnie zabarwione marksizmem) należy też potraktować przekonanie: „Ja nasze jest zawsze wynikiem, produktem: wytwarza się ono poza naszymi plecami, wytworzone zostało w przeważnej części przed naszym na świat przyjściem” (L 9).

Nie zwalnia to, oczywiście, jednostki $z$ aktywnej, ukierunkowanej na działanie postawy życiowej. Zbigniew Kuderowicz wyjaśnia:

Dla Brzozowskiego człowiek okazuje się przedmiotem historii de facto tylko w tym stopniu, w jakim uznaje przeszłość swego narodu za wyznacznik swej aktywności i w jakim nawiązuje do narodowej tradycji. Uznanie człowieka za przedmiot historii [...] jest [...] formą uczestnictwa w dziejach ${ }^{6}$.

Podobnie jak większość modernistów, Brzozowski nie ma złudzeń co do silnej subiektywizacji dziejopisarstwa. Wynik dociekań zawsze zależny będzie od intelektualnej konstrukcji jednostki. W Ideach pisarz nawoływał, by „pamiętać, że to, co przedstawia się oddzielnemu historykowi jako fakt, jest zawsze już w pewnej mierze wytworem jego umysłowości, [...] zainteresowań itp"7. Pogląd ten nie pozostał bez wpływu na dzieła beletrystyczne autora Płomieni - jak stwierdza Marta Wyka:

Przekonanie o głębokim, choć nie zawsze uświadomionym, związku języka narracji historycznej i osoby narratora stanie się w konsekwencji podstawą historycznych fabuł powieściowych Brzozowskiego [...]. [C 370-371]

Strategię tę widać choćby w utworze Sam wśród ludzi. On to przecież - a konkretnie zawarta w nim wizja osiemnastowieczności - będzie głównym przedmiotem moich rozważań. Zanim jednak przejdę do jego analizy, warto po przytoczeniu ogólnych poglądów Stanisława Brzozowskiego na historię przyjrzeć się wyzierającemu $z$ innych dzieł pisarza zarysowi wizerunku XVIII stulecia.

Niezależnie od tego, po który tekst Brzozowskiego sięgniemy - Legendę Młodej Polski ${ }^{8}$, Idee, Głosy wśród nocy czy Pamiętnik - otrzymamy de facto zbliżony obraz Wieku Świateł. Konsekwencja ta, w przypadku omawianego autora wcale nieoczywista, nie zmienia faktu, że najbardziej wartościowe świadectwo poglądów Brzozowskiego na tę kwestię stanowi rozprawa Z powodu „Pamiętników” Saint-Simona, zawarta w Głosach wśród nocy. Zarysowuje ona obraz XVIII wieku jako czasu, gdy za wszelką cenę dążono do estetyzacji rzeczywistości. Pojawia się tu jednak ciekawy paradoks - estetyzacja ta nie służy bowiem tak naprawdę pięknu czy wytwor-

Kołaczkowski, op. cit., s. 218.

Ibidem, s. 218-219.

Z. Ku de rowicz, Artyści i historia. Koncepcje historiozoficzne polskiego modernizmu. Wrocław 1980, s. 43.

7 Brzozowski, Idee, s. 112.

8 W przypadku tego dzieła wspomnieć należy o wyjątku, jaki Br zo zow ski (zob. L 157) czyni dla braci Śniadeckich, Staszica i Konarskiego, którzy - jak pisze D. O s iń s ki (Stefan Żeromski wobec tradycji oświecenia. W zb.: Żeromski i inni. Red. M. Gabryś - Sławińska, M. J. Ols ze w ska. Lublin 2015, s. 62) - stanowia „wzorce postaw równe pozytywistycznej wspólnocie ducha”. 
ności samym w sobie, tylko walce o wpływy jako jej czysto utylitarne narzędzie. Jest zabiegiem uprzedmiotawiającym:

Dusza ludzka staje się tu przepysznie rzniętym kamieniem, w którym żaden promień, najlżejsza gra światła nie ginie. Pozornie istnieje ona tu tylko jako źródło towarzyskiego zadowolenia - jest ona orężem i służy w istotnej walce o śmierć i życie. Uśmiechem, tonem, żartem, szybkością odpowiedzi zdobywa się tu wpływ, łaskę monarszą, władzę, bogactwa, uznanie, miłość, przyjaźñ. [...] Niezręczność, śmieszność zabijają. [...] Bezpośrednie, pierwotne, zwierzęce życie musi być przetworzone na dowcip, dobry humor, wymowę i wtedy - rzecz dziwna - służy jak narzędzie w całkiem pierwotnej niemal walce o byt ${ }^{9}$.

Jednocześnie nawet dla tak niechętnego nierównościom społecznym, tak aktywistycznego umysłu, jakim mógł poszczycić się Brzozowski, istniało coś pociagającego w owym „stuleciu czystej towarzyskości” (P 143). Pisał on więc w Pamiętniku o tym wieku:

wytworzył przepysznych magnatów życia, ludzi, których nigdy nie można było zaskoczyć w stanie towarzyskiej bezpłodności, którzy promieniowali nieustannie energią i byli nie do zwyciężenia. To Sheridan, to Mirabeau [...], to Beaumarchais. [P 144-145]

Ich właśnie autor Dębiny uważał za „najpiękniejszy typ ludzki tego stulecia” (P 145). Na dowód jednak, że to, co piękne, nie zawsze musi być dobre, poprzedzał swoją refleksję stwierdzeniem o „połączeniu miękkości i perfidii”, o „dywanowym fałszu tego życia” (P 143), jakie wówczas wiedziono.

Podobnych konstatacji - świadczących choćby o strzępach jakiegokolwiek uznania - brakuje natomiast, gdy autor Mocarza odnosi się do XVIII-wiecznych prądów w „swojej naturalnej i najważniejszej dziedzinie aktywności umysłowej [...]” (C 367) - filozofii. Przyznając się do ukształtowania własnych wyobrażeń o wieku XVIII pod znaczaccym wpływem Heglowskiej Fenomenologii ducha (zob. P 53), zdaje się Brzozowski podzielać pogląd filozofa o zgubnym podobieństwie fundamentów myślenia opartego na wierze i myślenia oświeceniowego ${ }^{10}$. Pisząc o osiemnastowieczności - co prawda francuskiej, ale przecież to właśnie z tego kraju promieniowały na Europe tendencje oświeceniowe ${ }^{11}$, co doskonale poświadczaja choćby ścieżki intelektualne niektórych bohaterów powieści Sam wśród ludzi-krytykował "wytworny artyzm, ukryty poza prostacka filozofia” ${ }^{2}$. Idee racjona-

9 S. Brzozow s ki, Głosy wśród nocy. Studia nad przesileniem romantycznym kultury europejskiej. Z teki pośmiertnej wydał i przedmową poprzedził O. Ortwin. Wstęp C. Michalski. Posł. A. Bi elik-Robs on. Wyd. 2, krytyczne. Warszawa 2007, s. 218.

10 W dziele G. W. F. Hegl a Fenomenologia ducha (Przeł., objaśn. A. La n d ma n. T. 2. Warszawa 1965, s. 138) czytamy:

„[...] Oświecenie ogłasza wiarę za błąd, za zmyślony pogląd na to samo, czym ono - Oświecenie jest.

Ale Oświecenie, które chce wiarę nauczyć nowej mądrości, nie mówi jej nic nowego. Dla wiary bowiem przedmiotem jest to samo, co dla Oświecenia, mianowicie czysta istota własnej świadomości, tak iż nie zatraca się ona w tym przedmiocie i nie zakłada siebie w nim jako zaprzeczonej, lecz raczej mu ufa, tzn. odnajduje w nim siebie jako tę oto świadomość, czyli jako samowi e d $z$ ę".

11 Ponieważ chodziło nie tylko o idee oświeceniowe, B r z o z o w s k i utyskiwał: „Na naszym [...] życiu umysłowym Francja nie przestaje ciążyć, ale dla nas właśnie te dogmatyczne fikcje pozażyciowych francuskich środowisk stają się samą, przed chwilą właśnie poznaną rzeczywistością" (L 411). 
listów uważał za „czcze, naiwne, puste, gadatliwe”, zwłaszcza wtedy, „gdy się z nich układa niepodobną do zniesienia "ewangelię oświecenia"”, i dodawał, że zwolennik racjonalistycznego światopoglądu „łudzi się, gdy myśli, że jego przekonanie płynie z dowodów: rzeczy mają się odwrotnie"13.

Czytelnik niniejszego artykułu zorientował się, być może, iż brak jakiejkolwiek informacji dotyczącej widzenia przez Brzozowskiego XVIII-wiecznych dziejów Rzeczypospolitej. Istotnie bowiem - temat ten nie był przez pisarza szeroko eksploatowany ${ }^{14}$. Jednakże pojedyncze wzmianki publicystyczne, którymi dysponujemy, sa dość wymowne. W Narodowych kłamstwach Brzozowski protestował przeciwko propagandzie obrońców wielkiej własności ziemskiej, nazywając ich „garścią nieodrodnych wnuków targowiczan”, która „nastaje na to, że miliony ludzi ma i nadal żyć na wpół bydlęco, byle tylko ich p raw a, owe fundamentalne prawa własności, nie zostały naruszone [...]"15. W podobnej retoryce utrzymany jest passus dotyczący „indygienatu szlacheckiego”, który „od czasów Szczęsnego Potockiego i Katarzyny II aż po dzień dzisiejszy znaczy książka służbowa, zapewniająca i to nie nazbyt zaszczytne miejsce w przedpokojach Petersburga, Berlina, Wiednia” ${ }^{16}$. Sugestywność tych sformułowań nie wymaga dodatkowego komentarza - wpisują się one w popularne ukazywanie postaw zachowawczo-ugodowych jako ideowo i moralnie dziedziczących z niesławnego dorobku konfederacji targowickiej.

\section{Historyzm Samego wśród ludzi}

Przedostatnia powieść Stanisława Brzozowskiego jest chyba szczytowym osiagnnięciem w jego beletrystycznym dorobku; potencjałem dorównuje jej jeszcze Książka o starej kobiecie. To jednak, co w przypadku pierwszej z nich - choć powoduje niedosyt - pozwala de facto na odbiór dzieła jako na swój sposób kompletnego, skazuje tę drugą na niemożność pełnej oceny. Chodzi, rzecz prosta, o nieukończenie obydwu tekstów. Książki o starej kobiecie powstał zaledwie kilkudziesięciostronicowy fragment; w przypadku Samego wśród ludzi dysponujemy całym tomem pierwszym planowanej dylogii oraz bardzo niewielka cząstką tomu drugiego. Autor pisał o swoich zamierzeniach:

Powieść byłaby duża [...]. Byłaby kroniką rodzinno-społeczno-szlachecką - z czasów 1840 mniej więcej - aż po 1870 i później. [...] nie tyczyłaby się prostych subiektów - lecz struktury typów ${ }^{17}$.

Warto też przytoczyć kilka zdań z listu, w którym Brzozowski bardziej szczegółowo omawia fabułę planowanego cyklu:

13 Ibidem

14 Wyjątek pod względem wykorzystywania wątków związanych z polskim wiekiem XVIII stanowić może właśnie powieść Sam wśród ludzi, lecz również z pewnymi zastrzeżeniami, o czym jeszcze będzie mowa.

15 S. Brzozowski, Narodowe kłamstwa. W: Opętane zegary. Wybór publicystyki społeczno-politycznej z lat 1905-1907. Wybór, wstęp A. M e n c we l. Warszawa 1986, s. 55 (Pierwodruk: „Przegląd Społeczny" 1906, nr 17).

16 Ibidem, s. 56.

17 S. Brzozows ki, Listy. Oprac., przedm., koment., aneksy M. Sroka. T. 1: 1900-1908. Kraków 1970, s. 432. 
Idea Dębiny [taki tytuł nosić miała cała dylogia - P. M.] jest taka. Polska upadła de nomine, złączona $\mathrm{z}$ resztą ludzkości katolicyzmem. [...] Bohater mój wyrusza w świat. Wszystko to aż nazbyt dramatyczne. I etap Berlin - lewica hegeliańska, Schule der Freien. [...] W sumie świat europejski jest tak samo opuszczony i sam jak i Polska. Nic nie ma ${ }^{18}$.

Dalsza część opisu dotyczy już nie zrealizowanych zamiarów fabularnych, mających stanowić trzon kolejnego tomu. Dowiadujemy się o planowanym przez Brzozowskiego samobójstwie Romana Ołuckiego (protagonisty Samego wśród ludzi) i udziale jego syna (kolejnego głównego bohatera) w powstaniu styczniowym. W końcu miał pojawić się wnuk Romana, socjalistyczny agitator, który - ginąc za głoszoną ideologię - przekonuje do niej swojego ojca ${ }^{19}$.

Również bezpośredni przodkowie samego Romana Ołuckiego należą do najważniejszych reprezentantów postaw, wobec których dorastający mężczyzna będzie zmuszony się określić. Słowo „wobec” jest tu niejako centralne; można nawet rzec, że bohaterowie Brzozowskiego wychowują się nie w rodzin ie, ale samodzielnie właśnie wo bec niej ${ }^{20}$.

O ile ojciec młodego Ołuckiego, Konstanty, uczestnik wojen napoleońskich, hulaka i „cielesny wizerunek szlacheckiego temperamentu” ${ }^{21}$, nie będzie nas zbytnio interesował, o tyle kasztelan Marcin Ogieński - dziadek Romana, teść Konstantego - jest postacia niezwykle istotną dla powieściowego obrazu osiemnastowieczności. Co ciekawe, podobnie jak praktycznie wszyscy bohaterowie tej - bądź co bądź - historycznej powieści (zob. C 89), stanowi kreację całkowicie fikcyjną. Wynika to $\mathrm{z}$ zamiaru „przeniesienia punktu ciężkości treści historycznej ku wnętrzu [...]”; z pragnienia „charakteryzowania nie zdarzeń historycznych, nie postaci historycznych, ale umysłowości i postaw duchowych, idei czasów" 22 . Tedy, jak pisze Jerzy Maciejewski, ,roi się w tym tekście, podobnie jak w Płomieniach, od rozmaitych kreacji postaciowych, które są symbolicznymi odpowiednikami określonych struktur kulturowych i historycznych"23.

\section{Epitafium dla "ostatniego z cywilizowanych". Kasztelan Marcin Ogieński}

Pierwszą z dwóch czołowych postaci-figur będących spadkobiercami umysłowości XVIII wieku ${ }^{24}$ jest wspomniany Marcin Ogieński, kasztelan na zamku w Kopajgrodzie. Kreacja ta pomyślana i zrealizowana została w sposób niezwykle efektowny;

Ibidem, s. 731-732.

Zob. ibidem.

A. M e n c wel (Stanisław Brzozowski-kształtowanie myśli krytycznej. Warszawa 1976, s. 82-83) zauważa, że „przypadek Brzozowskiego jest g r a n i c zny w swoim odejściu od [...] modelu idealnego rodziny w jej funkcji społecznej. Jest to taki przypadek, w którym rodzina nie spełnia ża dny ch pozytywnych funkcji w kształtowaniu osobowości, w którym c ała treść relacji rodzinnych jest czysto negatywna [...]. [...] przede wszystkim rodzina nie uzbraja i nie przygotowuje osobowości do wejścia w inne, pozarodzinne systemy społeczne zbiorowości [...]”.

Ibidem, s. 69.

Kołaczkows ki, op. cit., s. 229.

J. Z. M a ci je w s ki, W kłębowisku przeciwieństw. Obraz idei $w$ prozie narracyjnej Stanisława Brzozowskiego. Warszawa 1974, s. 77.

Drugim reprezentantem „osiemnastowieczności” będzie ksiądz Klemens Rotuła; analiza tej postaci stanowi dalszą część niniejszej pracy. 
swego uznania dla niej nie krył choćby Andrzej Mencwel, podziwiając „wspaniała postać starego kasztelana, Ogieńskiego, ostatniego prawdziwego reprezentanta Wieku Świateł, otwierająca swą autocharakterystyką Samego wśród ludzi" ${ }^{25}$. Owa autocharakterystyka, zawarta w liście pana Marcina do jego krewniaka z Francji, pana de Vandal, stanowi swoiste kompendium wiedzy o kulturze salonów wieku XVIII, obumierającej $z$ wolna, wyradzającej się na peryferiach Europy w pogardę dla wszystkiego, co nowe i zmuszające do czynu. Już samo miejsce, w którym znajduje się rezydencja Ogieńskiego - podolskie miasteczko Kopajgród - jest znaczące. Oprócz podnoszonego przez Wykę wyboru kresów przez Brzozowskiego jako silnie sprzężonych $z$ rodowodem polskiego romantyzmu (zob. C 91), warto zwrócić uwagę na inny istotny fakt. To na kresach przecież położone jest miasto Targowica; z tamtych terenów pochodzili wszyscy trzej przywódcy niesławnego porozumienia: Stanisław Szczęsny Potocki, Seweryn Rzewuski i Franciszek Ksawery Branicki. Ma to znaczenie o tyle, że sam kasztelan Ogieński również zgłosił akces do konfederacji targowickiej (zob. S 35).

Także forma epistolarna, w jakiej Brzozowski zapoznaje nas z postacią i zarysem umysłowości kasztelana, nie jest przypadkowa. Nie chodzi tu tylko o polifoniczność i o udostępnienie bohaterowi rozbudowanej, swobodnej formy wypowiedzi, w której ukaże on „światopoglądową panoramę XVIII stulecia, formułę wieku oraz jego ideologii, uczuciowości i doznań historycznych" (C 133). Paul Hazard przypomina bowiem o szczególnej wśród bywalców XVIII-wiecznych salonów, do których kasztelan niewątpliwie się zaliczał, predylekcji do listownej formy komunikacji (czy może raczej, posługując się dzisiejszym językiem, autoprezentacji):

Nigdy termin „korespondować” nie miał równie głębokiego sensu. Listy, kontynuacja rozmowy, zachowują całą jej żywość; ich autorom wydaje się, że ciaggle jeszcze biorą udział w rozmowie, $z$ dala od salonu, do którego przenosi ich tęsknota ${ }^{26}$.

Przecież tęsknota Ogieńskiego przenosi go w głównej mierze w czasie - ku minionej, oświeceniowej epoce, zniszczonej przez „te wszystkie wypadki lat czterdziestu” (S 4) ${ }^{27}$, ku epoce Cagliostra i Casanovy, o której kasztelan pragnałby napisać (odwołując się do gatunku gnomicznego, podobnie jak listy niesłychanie popularnego w XVIII wieku) w dziele Maksymy i spostrzeżenia ostatniego z cywilizowanych (S 9). „Ostatniego”, bo nie tylko Roman Ołucki jest w powieści Brzozowskiego „samym wśród ludzi". Piotr Dejneka zauważa:

samotność jako egzystencjalna przypadłość człowieka, jej rozpoznawanie, oswajanie i zwalczanie są stale widoczne na kartach twórczości autora Legendy Młodej Polski. Widać to począwszy od wczesnych rozważań nad sztuką, [...] a skończywszy na twórczości literackiej28.

Me ncwel, op. cit., s. 69.

P. H a zard, Myśl europejska $w$ XVIII wieku od Monteskiusza do Lessinga. Przeł. H. S uw ała. Warszawa 1972, s. 212.

Akcja powieści toczy się około roku 1830, chodzi więc zapewne o rozbiory Polski (którym nb. kasztelan nie był zbytnio przeciwny) $\mathrm{i}$ - przede wszystkim - o rewolucję francuską oraz o czasy napoleońskie - wydarzenia ostatecznie kładące kres porządkowi i kulturze ancien régime, z którą bohater się utożsamia.

P. D e j n e ka, Sam wśród filozofów. Alienacje i próby ich przezwyciężenia w twórczości Stanisława Brzozowskiego. Warszawa 2011, s. 11. 
Poczucie alienacji wydaje się więc też nieobce staremu kasztelanowi. Samą treść listu do pana de Vandal trafnie opisuje Krzysztof Fiołek; warto przytoczyć fragment jego artykułu:

Pisząc [...] list będący mieszaniną erudycyjnych uwag, towarzyskich uprzejmości i karykaturalnego krasomówstwa, kreśli sugestywny autoportret.

[...] rozczarowany życiem humorysta daje raz za razem próbę własnego smaku [...]. Manifestuje swe oczytanie, wzmiankując panią de Staël, Rousseau czy Condillaca. Poprzez takie zabiegi wyłania się bardzo specyficzny konserwatysta, który na chrześcijaństwo patrzy przez okulary Edwarda Gibbona, a do Klemensa Metternicha pisze listy. Pomstuje w nich, ,że nie do zniesienia jest stan rzeczy, w którym każdy musi być stróżem własnych lokajów i pilnować ich, aby się nie zepsuli”29.

\section{W dalszej części refleksji nad postacią Marcina Ogieńskiego badacz stwierdza:}

Kasztelan stara się trzymać jak najdalej od przesądów, wiązanych głównie z religią, [...] od radykalizmu społecznego czy narodowego, który konsekwentnie mianuje jakobinizmem. Pojawia się zabieg, który uważam za kluczowy dla metody krytycznej Brzozowskiego, a mianowicie kompromitowanie idei poprzez obyczajowość z nich wywiedzioną.

[...] Kasztelan wierzy w przezorność i doświadczenie dyplomatyczne Zamoyskich, Potockich, Branickich, Krasińskich [...]. Czytelnik nie może mieć żadnych wątpliwości co do tego, że strachem o stan posiadania są motywowane wszystkie antypowstańcze filipiki Ogieńskiego [...].

Kryterium obyczajowo-towarzyskie jest zupełnie pierwszorzęne, łagodzi lub wzmaga ideowe rozbieżności. Ogieńskiemu bezbrzeżnie więcej imponuje salonowiec [i targowiczanin] Kossakowski niż ,jakobin” Kościuszko. [...] W samych superlatywach opisuje Ogieński wnukowi czasy swej młodości, kiedy to „oddychało się dowcipem i dobrymi manierami”, a ,jedno powiedzenie czyniło cię sławnym”, bo „Europa to było towarzystwo dziesięciu tysięcy świetnych osób” i „nikt nie czuł się osamotniony”30.

Wzmianka o „kompromitowaniu idei poprzez obyczajowość z nich wywiedzioną” wydaje się tu szczególnie cenna. Zresztą nie tylko ona jest tej kompromitacji narzędziem - podobna funkcję zdają się spełniać w przypadku Marcina Ogieńskiego domniemane źródła części jego przekonań, przestrzeń otaczająca bohatera czy pewne archetypiczne wzory jego postaw.

$\mathrm{W}$ przypadku pierwszego $\mathrm{z}$ tych trzech zagadnień warto zwrócić uwagę na racjonalizm, którym szczyci się kasztelan („Je suis cartésien i nie ma nic wstrętniejszego niż to wasze współczucie" $\langle$ S 21 $\rangle$ - deklaruje). Otóż w Ideach czytamy:

Racjonalizm [...] przemawiał do przekonania szlachty, gdy już nie była ona pewna swych obyczajów, gdy nie miała żadnego typowego wzoru życia. [...] gdy w jakiejś klasie wzór ten został utracony i powodzenie lub niepowodzenie stają się zależnymi od przypadku, dojrzała ona do racjonalizmu demoralizującego ją. Może ona żyć indywidualnymi przyzwyczajeniami, ale nie może zbiorowo myśleć; każdy jej przedstawiciel czuje się zachwycającym wyjątkiem i im bardziej ceni swą wyjątkowość, tym łatwiej mu poświęcić klasę 31 .

Trudno nie odnieść wrażenia, że przekonanie kasztelana o sile rozumu - przede wszystkim własnego i ludzi sobie podobnych - jest właśnie swoistą strategią obronną, pomagającą w anachronicznym trwaniu. Podobnie rzecz ma się z zapewnienia-

K. Fi ołe k, W płomieniach polskości. Stanisław Brzozowski wobec „sprawy narodowej”. W zb.: Stanisław Brzozowski. Powroty. Red. D. Trz e śn n o w s ki. Radom 2013, s. 135-136.

30 Ibidem, s. 136-137. Te - nieco przydługie, można by sądzić - cytaty wydaja mi się konieczne. $Z$ racji swej celności zwalniają bowiem od ponownego opisywania rzeczy raz już opisanych oraz pozwalają czytelnikowi zorientować się w podstawowych składowych kreacji postaci, przy założeniu których będą prowadzone dalsze rozważania. 
mi Ogieńskiego o jego, „ostatniego z cywilizowanych”, e u r o p e j s k o ś c i. Nadużywanie tego pojęcia krytykował Brzozowski w Legendzie Młodej Polski, dostrzegając w nim fasadę dla pielęgnacji „swoistego, sielankowego, sentymentalnego, obłudnego nihilizmu" (L 264). Zwalnia on - w tym przypadku w obliczu niemożności komunikacji z reprezentującymi nowe czasy „barbarzyńcami”, ,jakobinami” i „lokajami” z obowiązku jakiejkolwiek aktywności; powoduje zanik „samego pojmowania mężnej, odpowiedzialnej woli”, pozwala bez odrazy przeglądać się w „tafli zastoju” (L 264).

Wszystko to - racjonalizm, odwoływanie się do europejskości i zachodniej (niemal nigdy polskiej!) literatury, przybierajace niekiedy znamiona idolatrii ${ }^{32}$ - jest tylko formą utwierdzania samego siebie w przekonaniu o swojej wyższości. Wypada w tym miejscu przytoczyć kolejny pogląd zawarty w Legendzie Młodej Polski, a idealnie korespondujący z postawą Ogieńskiego. Oto opisując sytuację kulturową polskiej szlachty, Brzozowski zauważa, że kultura była dla niej „zamorską nowinką, czymś, czym można w razie potrzeby sobie i innym oczy ćmić: nie była własnym, tu stwarzanym dziełem” (L 95).

Podupadłe, przebrzmiałe koncepcje, składające się na poglądy kasztelana, znajdują w otaczającej go przestrzeni swoją symbolikę. W symbole - tak ważne dla pisarstwa Brzozowskiego ${ }^{33}$ - obfitują kopajgrodzkie postaci, zwierzęta i przedmioty:

Pałac kopajgrodzki wyludniał się coraz bardziej i posępniał; snuła się po kurytarzach służba zestarzała, pełna dziwacznych przyzwyczajeń; nie odnawiana liberia różnych antyków lokajskiego rodu, dziwaczna, zbrukana, maskaradowa elegancja dwóch czy trzech niegdyś faworytek pana kasztelana, nieprawidłowo nakręcane zegary [...], osowiałe, zapasione pinczery [...]. Od czasu do czasu umierał ktoś ze starych weteranów liberyjnych; w pewien dzień jesienny szedł pod topolami, z których leciały liście, kondukt masek; $z$ podwiązanymi zębami [...] szła, chuda jak tyka, niegdyś markiza $z$ Parc-aux-Cerfs kopajgrodzkiego, wlokły się figury w perukach, harbajtlach [...]. Umarł „młodszy”, poza siedemdziesiątkę sięgający kamerdyner. [...] Kasztelan gadał z ptakami, uczył je śpiewek i wykrzyków; doprosić się nie mógł starej i złej papugi, by krzyczeć się nauczyła „Magdalena! Magdalena”. [...] ptak milczał albo [...] wykrzykiwał „Kusy! Kusy!” - wyraz, który przyswoił sobie od pana Ołuckiego, z nawoływań jego na ogara. [S 171-172]

Cały ten fragment obrazuje de facto obumieranie - używając słów Wyki - „ostatnich pozostałości stanisławowskiego świata”; zamku - „symbolu klasycystycznej ruiny" (C 92). Centralny punkt opisu stanowi pochód chwiejnych postaci, wlekacych się niby mary. Stylizowany bodaj na średniowieczny danse macabre, stracił - podobnie jak kopajgrodzkie zegary - rachubę czasu. Znacząca jest też papuga, mimo usilnych żądań kasztelana śpiewająca pieśń witalizmu, który w powieści reprezentuje Konstanty Ołucki i jego - zapewne wykorzystywany do leśnych gonitw - ogar. Tak jak Roman „nawiązuje [...] ze światem, w obrębie którego egzystuja psy myśliwskie, dziki, konie rasowe, psychiczną łączność” ${ }^{4}$, tak Ogieński „od lat czuł się spokrewnionym” z ,wersalskimi papugami i niektórymi pinczerami” (S 224). Symbolika tego kontrastu sprawia wrażenie aż nazbyt czytelnej, zwłaszcza że papuga $\mathrm{z}$ pewnością nie należy do ulubionych przez autora Płomieni reprezentantów fauny ${ }^{35}$.

Zob. S 21: „Gdyby Duch Święty podyktował apostołom choć jedno powiedzenie pana de Chamfort lub de Ligne’a, zaraz bym się nawrócił i kazał ochrzcić".

35 W noszacym znamienny tytuł $Z$ nekrologii artykule S. Brzozowskiego (w: Opętane zegary, 
Metaforą odchodzącego świata jest też rozpadająca się ozdobna figurka. Którejś nocy Kasztelan:

nieopatrznie wypuścił z rąk statuetkę z sewrskiej porcelany; rozbiła się w drobne okruchy. „To już nigdy nie będzie istniało i ja nie będę istniał; [...] je suis de la porcelaine, qui se souvient [...]" [...], ale po chwili pochylił się nad okruchami swej figurki i chciał je dosztukowywać: były zbyt drobne [...]. [S 170]

Ucieczka ku „skamieniałościom życia minionego” (L 108) okazuje się tedy niemożliwa.

Na koniec rozważań dotyczących kasztelana Marcina Ogieńskiego ${ }^{36}$ warto zastanowić się, jakie miejsce zajmuje on wśród typów XVIII-wiecznych libertynów. Do takowych z pewnością bowiem się zaliczał, jeśli uwzględnić jego ateizm, liczne (niegdyś) faworyty i romanse ${ }^{37}$, a za libertynizm uznać - za Jerzym Snopkiem - XVIII-wieczne „rozluźnienie w dziedzinie moralności” i erotyki oraz „drwinę i nierzadko szyderstwo pod adresem Kościoła i religii” (O 9). Jerzy Łojek zaś przedstawia kolejny aspekt oświeceniowego ruchu, który charakteryzuje postępowanie kasztelana:

Pogarda dla obiegowej normy moralnej i zasad etycznych „dobrych dla gminu” skłaniała libertyna do przyznawania nielicznym tylko, sobie podobnym ${ }^{38},[. .$.$] pełnych praw i do traktowania ich jako part-$ nerów; istoty, które nie dorosły umysłowo i moralnie do wyzwolenia się z przesądów i wzniesienia się ponad obyczajowe konwencje, mogły być dlań tylko przedmiotem lub narzędziem działania ${ }^{39}$.

W zaproponowanej przez siebie typologii „literackich wzorów postaw libertyńskich” (O 84) Snopek wyróżnia tzw. „libertynizm arystokratów” (O 132). W wielu punktach wykazuje on zbieżność z tym, co jest (albo było) udziałem Ogieńskiego: wysoka pozycja społeczna, zapewniająca beztroskie (przynajmniej do czasu) życie, liczne wojaże po salonach europejskich, a także - nieoczywiste wcale wśród libertynów ${ }^{40}$ - „skupienie całej uwagi na problematyce szczęścia jednostki ludzkiej, zaniechanie zaś refleksji na temat szczęśliwego życia i harmonii społeczeństw" (O 134). Taką właśnie postawę - eudajmonistyczną, nienawistną przecież Brzozowskiemu $^{41}$ - reprezentował dziadek Romana Ołuckiego.

\section{Libertyn dziecięcej wiary. Ksiądz Klemens Rotuła}

Drugim z „XVIII-wiecznych” bohaterów Samego wśród ludzi jest wspominany już kopajgrodzki ksiądz, Klemens Rotuła. Kreacja ta, wybitna w nie mniejszym stopniu niż Marcin Ogieński, nie umknęła uwadze choćby Czesława Miłosza. W opowiada-

s. 52) z „Przeglądu Społecznego” (1906, nr 16) ptak ten reprezentuje inercję oraz szybko gasnący zapał: w obliczu czynu „dziękuje, kłania się i pozostaje w dziedzinie symbolu”.

Chodzi o rozważania poświęcone wyłącznie tej postaci; kontekstowo pojawi się ona bowiem jeszcze na kolejnych stronicach pracy kilkakrotnie.

37 Zob. S 54: „Pan kasztelan [...] za rozpustnika się wielkiego uważa - że to dziewczęta w koronki poubierał, w mleku kapać każe, perfumami oblewa i dopiero przyjdzie sam” - kpi Rotuła.

38 A więc owym „dziesięciu tysiącom świetnych osób”, o których wspomina kasztelan.

39 J. Łoj ek, Crébillon młodszy i jego współcześni, czyli libertynizm uśmiechnięty. W: Wiek Markiza de Sade. Szkice z historii obyczajów i literatury we Francji XVIII wieku. Lublin 1975, s. 13-14.

40 Spojrzeć wystarczy na tzw. „libertynizm outsidera”, reprezentowany według Snopka (O 105) przez T. K. Węgierskiego, który „Z bólem i sarkazmem pisał o niesprawiedliwości”.

41 Zob. np. M. Wy ka, wstęp w: S LXXI-LXXII. 
jącej o autorze Płomieni książce Człowiek wśród skorpionów noblista trafnie zarysowuje sylwetkę duchownego jako ,jakobina, libertyna (i dziwkarza), a zarazem człowieka dziecięcej wiary”, tytułując go przy tym „najdoskonalszą kreacją literacką Brzozowskiego i najgłębiej ujętą postacią księdza w polskiej, a może i światowej literaturze" 42 .

Więcej miejsca poświęca Rotule badacz wątków religijnych w naszej literaturze przełomu XIX i XX wieku, Dariusz Trześniowski. W swoim artykule dotyczacym stosunku Brzozowskiego do polskiego Kościoła zawarł on kilka uwag charakteryzujących tego bohatera:

Księża Brzozowskiego wywodzą się z konserwatywnych środowisk społecznych. [...] Rotuła jest chłopem. Wartości religijne, w postaci katechizmu, zostały im wpojone w procesie tradycyjnego wychowania [...]. Rotuła z dzieciństwa zapamiętał „baśń o cudownym przeznaczeniu człowieka [...]”33.

Trześniowski podkreśla też, że:

Rotuła był dzieckiem oświeceniowego przewrotu myślowego Woltera i Rousseau, świadkiem wielkich wydarzeń politycznych, jak wojny napoleońskie, powstanie listopadowe. Sądził, że Polskę mogłaby uratować radykalna rewolucja antyfeudalna, wzorowana na francuskiej ${ }^{44}$.

I wreszcie stwierdza:

Rotuła nie miał skrupułów. Wyniesiony z XVIII wieku libertynizm zdejmował zeń wyrzuty sumienia. Nie krył się ze swymi kochankami i nie uważał, żeby ten fakt podawał w wątpliwość jego święcenia kapłańskie ${ }^{45}$.

Ostatni cytat może nieco dziwić; akapity Samego wśród ludzi poświęcone kopajgrodzkiemu duchownemu pełne są bowiem jego wyrzutów sumienia $z$ racji własnej konduity. Snopek przypomina, że „linia podziału między libertynizmem a prawowiernościa przebiegała często nie pomiędzy ludźmi, ale właśnie w nich" (O 85). Tak było i z Rotuła, w którym te dwie siły toczyły nieustanną walkę, niestety dla księdza, a ku uciesze czytelnika - nierówną. Motywowany erotyczną żądzą libertynizm ścierał się z „prawowierną” religijnością, za którą tak naprawdę stał strach duchownego przed śmiercią i ewentualnym potępieniem. Ów lęk właśnie, a nie żal za grzechy, kazał mu rozmyślać o zdradach i defraudacjach, których się dopuścił w czasach rewolucji francuskiej. Najbardziej wstrząsajacy chyba epizod z młodości Rotuły tak oto zostaje opisany:

na tym przeklętym statku pod pokładem, wśród nocy, doczekawszy się, aż zaśnie towarzysz, zjadał Rotuła w ukryciu przechowywany suchar, pił łyk wódki. I tak przez pięć nocy, w ciągu których tamten umierał. [S 114]

Wspomnieniom tym towarzyszyła „okropna myśl, że to nie jest żal - ale strach śmierci. [...] że nie myśli o Polsce, że w obliczu śmierci został sam ze swoim strachem o siebie" (S 114-115).

Cz. Mił o s z, Człowiek wśród skorpionów. Warszawa 1982, s. 110.

D. Trześni ow ski, Od negacji do metafizyki zaścianka. Stanisław Brzozowski wobec Kościoła polskiego. W zb.: Stanisław Brzozowski. Powroty, s. 65.

Ibidem, s. 66.

Ibidem, s. 67. 
Życie erotyczne składające się na libertyńskie oblicze księdza również przepełnione jest wyrzutami sumienia i goryczą. Podczas jednej $z$ alkoholowych libacji Rotuła wykrzykuje: „Chryste Panie! Po toś na krzyż wstapił, abym ja z Małgosią, Kaśką, Marysią... a powiadam ci, Panie Jezu, po coś żeś ty się tym wszystkim babrał” (S 53). W innym zaś miejscu kasztelan z właściwą sobie ironią zauważa:

Rotuła najpierw dziewce śpiewać sobie każe, potem sam nad sobą się rozpłacze, [...] że to i on, i Marysia czy Zośka sierotka, to się dwie sierotki jak te gołąbki przyhołubią, a potem znowu do niej: „Biednaś ty, nieszczęśliwa; wszyscy cię skrzywdzili i ja cię skrzywdziłem” [...]. [S 66]

Rotuła więc zasadniczo w każdej z ról, które w życiu na siebie przyjął, ponosi klęskę. Kapłan za winowajcę swojej zguby - nie bez podstaw zreszta - uznaje Ogieńskiego: ów, gdy tylko poznał młodego księdza:

spostrzegł, że Rotuła męczy się swą czystością, [...] postanowił mu przyjść z pomoca, [...] rozwijał przed nim „ewangelię Marii Magdaleny”. Bawił go ten syn chamski, który całkiem literalnie wierzył, że się tu w podolskiej chacie na anioła urodził [...]. [S 109]

To kasztelan roztaczał przed pochodzącym z głębokiej nędzy duchownym wizję ogólnej sprawiedliwości (,ziemi [...] dla wszystkich ludzi”, O 111), mającej być owocem działań rewolucyjnych z 1789 roku. Adept nauk młodego Ogieńskiego z gorliwością neofity rzucił się w wir nowych idei, nie zauważając, że jego mentor odnosił się do nich z pewnym dystansem, o czym sam wspomina:

jakeś to, pamiętasz, niewinność stracił, a ja ci mówiłem - żeś przyjęty został do kościoła ludzkości i rozumu. I ty zaraz na serio... Pamiętasz, jakeś to Ewangelię palił i listy pisał: „Twój uczeń w Voltairze”... [...] któż tobie jest winien, żeś nie miał taktu [...]. [S 112]

Wyrażenie „uczeń w Voltairze” nasuwa skojarzenie z innym dziełem Brzozowskiego. Paradoksalnie bowiem, choć sam był przecież reprezentantem stanu kapłańskiego, wydaje się Rotuła egzemplifikacją zawartego w Głosach wśród nocy ostrzeżenia przed przekształceniem się (skądinąd mających słuszność) krytyków klerykalizmu w „bractwo głuptasków w Wolterze” 46 .

Istotnie więc, rozpaczliwie powtarzane przez księdza pytanie: „Coś ty z moją duszą zrobił?” (S 111), zdaje się znajdować w kasztelanie właściwego adresata. Mefistofeliczny rys postaci Ogieńskiego staje sie jeszcze bardziej widoczny, gdy porównamy go $z$ - będącym chyba świadoma paralelą do relacji między dwoma mieszkańcami Kopajgrodu - wątkiem z księgi II (U drogowskazów zwidziska) Samego wśród ludzi. Chodzi mianowicie o rozgrywającą się w Berlinie historię lokaja, którego Roman spotkał w więzieniu, Karla. Jego chlebodawca, emerytowany generał, podczas towarzyskiego spotkania postanowił zawrzeć z kompanami spontaniczny „kawalerski zakład”. Przekonany o miałkości rozumu swego kamerdynera i jego bezgranicznym oddaniu, zadeklarował: „Mój Karl dla mnie duszę diabłu zapisze" (S 396). Zapewnienie generała, iż postapi tak samo, skłoniło lokaja do przypieczętowania własną krwią tego osobliwego „cyrografu”, mającego rzekomo wybawić jego chlebodawcę od konieczności spłaty karcianego długu. Prostoduszny Karl nie mógł sobie poradzić ze swoją decyzją; stopniowo popadał w coraz większy obłęd, 
którego finałem było morderstwo dokonane na chlebodawcy. Dla dalszego wyjaśnienia sytuacji udziela Brzozowski głosu dawnemu kompanowi generała, zeznającemu podczas procesu:

Prawie dwa lata żył człowiek z przekonaniem, że wszystko, co zrobi, jest właściwie już obojętne, los jego bowiem został raz na zawsze rozstrzygnięty [...]. Musiał więc [generał] powiedzieć coś bardziej ogólnego, coś, z czego Karl domyślił się, że to wszystko było żartem, żartem dla jenerała - czytelnika Nicolaiego ${ }^{47}$. [...] Otóż, co może być żartem dla jenerała, może nie być żartem dla Karla, nie być żartem dla diabła, na pewno nie jest żartem dla Chrystusa: a dusza już więc stracona i przez kogo? Przez własnego dowódcę oddana na pośmiewisko [...]. Gdy więc usłyszał $\mathrm{z}$ własnych ust jenerała, uśmiechniętych, lekko żartujących ust, jak strasznego padł ofiarą podejścia, musiał uczuć, jak w głębi piersi pękła mu ta napięta aż do bohaterstwa, aż do szału struna honoru wojskowego. [S 398-400]

Ksiądz, w przeciwieństwie do kamerdynera, nie musi się domyślać - kasztelan wprost mówi mu o swoim od początku kpiącym stosunku:

Mój ty drogi - jeżeli chcesz, to ci powiem, przykra to rzecz, mais tu étais un drôle d'une particulière espèce... Takiego nie widziałem - ja ci byłem szczerze wdzięczny - byłeś naprawdę interesujący... [S 111-112] $]^{48}$

Parafrazując przytoczoną wypowiedź powieściowego świadka sądowego, rzec by można, że nie wszystko, co jest żartem dla kasztelana, musi być żartem dla Rotuły. Rozgrywający się w Kopajgrodzie dramat nie wymagał cyrografu - wystarczyła tragedia potrzeby wiary i jej zrujnowania. Warto przy tej okazji zwrócić również uwagę na diametralnie różne postrzeganie wartości i funkcji słowa jako środka ekspresji przez obydwie postaci. Dla Ogieńskiego, hołdującego sposobowi bycia właściwemu XVIII-wiecznym salonom, słowo jest budulcem pozycji towarzyskiej, narzędziem do tworzenia efektownych powiedzeń, kreowania bon motów czy wreszcie własnego samozadowolenia. Kwestia odpowiedzialności za treść zawieraną we własnych oświadczeniach jest drugorzędna: jak przyznaje kasztelan, ,inna rzecz wypowiadać zdania, inna zaś je wyznawać” (S 4). Również i tym Ogieński gubi Rotułę, postrzegającego słowo w kategoriach epistemologicznych, zainteresowanego jego prawdziwością i biorącego je - co zostaje mu wytknięte - „na serio" 49 .

Co ciekawe, podobnie jak w przypadku kasztelana, postawa Rotuły znajduje swoje dość wierne odzwierciedlenie w typologii libertynów proponowanej przez

Christoph Friedrich Nicolai, o którym tu wspomniano, był XVIII-wiecznym niemieckim racjonalistą. Na marginesie warto odnotować jeszcze jedną beletrystyczną kreacje Brzozowskiego, która wykazuje daleko idące zbieżności z sytuacją Rotuły. Chodzi mianowicie o bohatera powieści Pod ciężarem Boga, Konrada Czyńskiego, byłego księdza, który - porzuciwszy wiarę i stan kapłański pod wpływem swej kochanki, Izy - zakłada wolnomyślicielskie, antyreligijne czasopismo. Nie mogąc ostatecznie uwolnić się od wizji istnienia Boga, targany strachem przed potępieniem, wypowiada w kierunku dziewczyny znamienne, nie wymagające chyba komentarza co do zbieżności z Samym wśród ludzi, słowa: „Tyś mnie zgubiła! Tyś duszę moją zgubiła! Ja przez ciebie męki piekielne cierpieć będę..." (S. B r zoz ow s k i, Pod ciężarem Boga. W: Pod ciężarem Boga. - Wiry. - Płomienie. Posł. M. Wy ka. Kraków 2012, s. 101). Intrygujący jest też - powtórzony w Samym wśród ludzi pod postacią przywoływanego wspomnienia Rotuły z podróży statkiem - motyw nieudzielenia pomocy osobie potrzebującej: „Nagle przyszedł mu [tj. Czyńskiemu] na myśl jeden z jego kolegów szkolnych, któremu pozostał winien trzysta rubli i który umarł w nędzy” (ibidem, s. 52).

Widać to w reakcjach emocjonalnych księdza na krytykę i wypominanie przewin tak przez Romana, jak i przez Ogieńskiego. 
Snopka. Oto badacz wyszczególnia w swojej klasyfikacji tzw. libertynizm duchownego, egzemplifikując go losami Adama Naruszewicza. Zadziwia ilość podobieństw między dziejami powieściowej postaci a historią wielkiego XVIII-wiecznego poety-biskupa, o którym czytamy:

Naruszewicz jest ucieleśnieniem walki starego z nowym. Wychował się i wykształcił [...] w środowisku klerykalnym [...].

Jeśli idzie o ograniczenia, to w równym stopniu krępował Naruszewicza cały rynsztunek światopoglądowy, w jaki wyposażyli go bogobojni rodzice, jak i jezuicka edukacja. Trzeba było dopiero owego potężnego parcia ducha epoki, w której centrum Naruszewicz się znalazł, by w jego światopoglądzie zaczęły powstawać coraz liczniejsze pęknięcia i wyłomy. Osoba uwielbianego króla stanowiła żywe antidotum na wyrzuty sumienia. Zaczęła dochodzić do głosu zmysłowa natura [...]. [O 85-86]

Gdyby nie jezuicka edukacja, której Rotuła nie posiadał (tak jak Naruszewicz jakobińskiego epizodu), a także kolosalna różnica w usytuowaniu obydwu postaci w hierarchii społecznej, można by powiedzieć, że przytoczony opis jest wiernym odzwierciedleniem drogi duchowej kopajgrodzkiego kapłana. Szczególną uwagę zwraca pojawiająca się w obu opowieściach postać swoistego „kusiciela” czy „inicjatora” zmiany światopoglądu, skutecznie zagłuszającego (przynajmniej do czasu) strach przed potępieniem lub wyrzuty sumienia. W powieściopisarstwie Brzozowskiego staje się ona - jeśli oprócz Rotuły wyliczyć lokaja Karla oraz niektórych bohaterów pozostałych utworów, choćby wspomnianego Czyńskiego - swoistym leitmotivem, wartym, być może, osobnego namysłu.

„Wiek osiemnasty tryumfował” (S 126) - czytamy w Samym wśród ludzi po tym, gdy główny bohater, dorastający Roman Ołucki, po raz pierwszy wejdzie nocą do pokoju córki jednego ze służących w kopajgrodzkim zamku. Bezceremonialnie, choć z pewnym do siebie obrzydzeniem, zapyta chwilę wcześniej jednego z lokajów: „A Margot gdzież tutaj sypia?” (S 125). Ta krótka scena jest w dużej mierze symboliczna dla postrzegania osiemnastowieczności w pierwszym i jedynym tomie Dębiny. Na rozwiązłość erotyczną jako komponent kultury XVIII-wiecznej wskazuje wszak Brzozowski dobitnie, uznając przecież etykę - w tym płciową - za niezwykle istotny aspekt porządku społecznego ${ }^{50}$.

Ilość akcentów negatywnych, w które wyposażone zostają Brzozowskiego powroty do XVIII wieku, wyklucza w zasadzie elementy pozytywne. Z pewnościa spowodowane jest to określoną wrażliwością artystyczną twórcy (a także polskiego modernizmu jako takiego), wzdragającego się raczej przed tym, by w swych dziełach roztaczać świetlane lub choćby pogodne wizje. Dobitnie uwidacznia to kreacja dwóch omawianych tutaj bohaterów. Niezależnie, czy przenoszące ich ku wspomnianemu stuleciu reminiscencje mają charakter afirmacyjny (jak w przypadku Marcina Ogieńskiego), czy też pełne są żalu i odrazy do samego siebie (jak u Klemensa Rotuły) - nie ulega wątpliwości, że dramat obydwu wiąże się właśnie z kulturą i umysłowością wywiedziona z Wieku Świateł. Ich biografie wydaja się po prostu odpowiedzią na pytanie: Unde malum? - padające w kontekście „struktury duszy polskiej” 
kolejnych pokoleń przedstawionych w powieści Sam wśród ludzi. Tak naprawdę bowiem powrót do osiemnastowieczności w ujęciu autora Płomieni stanowi potwierdzenie jego idées fixes (i to nie tylko w podejściu do historii), przez które jest ona przefiltrowana. Wiek XVIII okazuje się tedy niezbędnym zbiorem problemów i postaw do przemyślenia w sytuacji stawiania pytań o źródła powikłań polskiej tożsamości; o szanse rozwojowe kultury narodowej i o możliwość radykalnej, prospołecznej przebudowy polskiej umysłowości.

Świadom jestem występowania w Samym wśród ludzi takich wątków, które choć pozwalają na uruchomienie kontekstów wiążących się z XVIII stuleciem - nie znajdują w niniejszym artykule swojego opisu. Warta uwagi byłaby też głębsza analiza postaci Ewarysta Zimorowicza: $\mathrm{z}$ jednej strony, archetypicznej wobec pozytywizmu, pochłoniętej prometejska wiarą w coraz to nowe naukowe (lub pseudonaukowe) teorie przyrodnicze, $z$ drugiej zaś - będącej „duchowym spadkobierca kasztelana Ogieńskiego, nieco bardziej nowoczesnym, znającym Saint-Simona oraz przykazania fourieryzmu, czytującym Benthama [...]" (C 100). Podobnie rzecz ma się $z$ ojcem Jerzego Flavela, bogatym angielskim plantatorem $z$ Indii Zachodnich „człowiekiem o układzie duszy angielskiego XVIII wieku” (S 259). Wszystko to jednak wątki o koło o si em na s tow i e c zn e, które wykraczaja poza temat tego wywodu; nie znaczy to przecież, że nie są warte podjęcia. Wręcz przeciwnie, pozostaje mieć nadzieję, iż znajdą swoich badaczy.

Abstract

PIOTR MISZTELA Institute of Literary Research of the Polish Academy of Sciences, Warsaw ORCID: 0000-0003-0869-7677

UNDER THE BURDEN OF ENLIGHTENMENT STANISŁAW BRZOZOWSKI'S $18^{\text {TH }}$ CENTURY BIOGRAPHIES AND DIAGNOSES IN THE NOVEL "SAM WŚRÓD LUDZI"

(“ALONE AMONG PEOPLE")

The subject of the article are references to the $18^{\text {th }}$ century in Stanisław Brzozowski's novel Sam wśród ludzi (Alone among People). $18^{\text {th }}$ century exponents in the novel are first and foremost the figures of Marcin Ogieński and priest Klemens Rotuła who in various ways struggle, in the face of the social-political changes that took place at the onset of the Age of Reason, with the fall of their ideals. The aim of the argument is a presentation of the references' functionalities as well as placing them against the background of Brzozowski's general creative and world view assumptions. In Brzozowski's reflection, returns to the $18^{\text {th }}$ century provide with opportunities to question for the roots of modernity and for the sources of the (negative) stances contemporary to him. The returns also co-create, which the author of the paper tries to prove, the cultural diagnoses and projects put forward by Brzozowski, as well as support the ethical conceptions. 